\title{
DETERMINAN TINGKAT EFISIENSI BANK PEMBANGUNAN DAERAH (BPD) SYARIAH DI INDONESIA: TWO-STAGE DATA ENVELOPMENT ANALYSIS 1]
}

\author{
Hilda Sukma Puspita \\ Mahasiswa Program Studi S1 Ekonomi Islam-Fakultas Ekonomi dan Bisnis-Universitas Airlangga \\ Email :hilda.sukma-13@feb.unair.ac.id
}

\author{
Atina Shofawati \\ Departemen Ekonomi Syariah-Fakultas Ekonomi dan Bisnis-Universitas Airlangga \\ Email :atina-o@feb.unair.ac.id
}

\begin{abstract}
:
This study aims to analyze the efficiency level of Sharia Regional Development Bank on the first stage and to analyze the influence of Bank Size, ROA, NPF, FDR and Inflation for the efficiency level of Sharia Regional Development Bank on the second stage. The population in this study is the Sharia Regional Development Bank in Indonesia. The sample used in this research is 14 Shariah Regional Development Bank that fulfill the criteria of taking the sample that is having Sharia Business Unit, presenting the financial statements and has been published, and no change of business entity. The observation period of the study is from 2012 to 2016. This researchanalysis technique used DEAP 2.1. on the one stage and Tobit on the twostage. The result of this study indicates that the Bank Size, ROA and FDR positif significant influence to efficiency level, while the NPF and Inflation don't have influence to efficiency level.
\end{abstract}

Keyword: Efficiency, Regional Development Bank (BPD) Sharia, Data Envelopment Analysis (DEA), Tobit Regression.

\section{PENDAHULUAN}

\section{Latar Belakang}

787 efinisi bank menurut Undanguriuuriy Perbankan No. 10 tahun 1998 menyatakan bahwa bank adalah badan usaha yang menghimpun dana dari masyarakat dalam bentuk simpanan dan menyalurkannya kepada masyarakat dalam bentuk kredit dalam rangka meningkatkan taraf hidup rakyat banyak. PSAK No. 31 menjelaskan bank adalah lembaga yang berperan sebagai perantara keuangan (financial intermediary) antara pihak yang memiliki dana dan pihak yang memerlukan dana, serta sebagai lembaga yang berfungsi memperlancar lalu lintas pembayaran.

Sejak di ubahnya Undang-Undang No. 7 tahun 1992 menjadi Undang-
Undang No.10 tahun 1998 tentang perbankan, industri perbankan di Indonesia mengalami kemajuan pesat. Pemerintah pun mengeluarkan regulasi yang mengatur secara khusus mengenai perbankan syariah melalui UndangUndang No. 21 tahun 2008. Adanya kedua undang-undang tersebut, pemerintah melakukan langkah strategis dalam pengembangan perbankan syariah ini yaitu pemberian izin Bank Umum Konvensional untuk membuka kantor cabang Unit Usaha Syariah (UUS) ataU dengan konvensi dari sebuah bank konvensional menjadi bank syariah (Pratikno dan lis, 2011). Hal ini membuat sistem perbankan di Indonesia menganut dual banking system. 
Puspita, et al/ Jurnal Ekonomi Syariah Teori dan Terapan Vol.5 No.10 Oktober 2018: 800-815; DETERMINAN TINGKAT EFISIENSI BANK PEMBANGUNAN DAERAH (BPD) SYARIAH DI INDONESIA: TWOSTAGE DATA ENVELOPMENT ANALYSIS

Pengertian Bank Pembangunan Daerah menurut Undang-Undang No. 13 tahun 1962 adalah bank yang didirikan di Daerah swatantra Tingkat । yang dimaksudkan untuk menyediakan pembiayaan bagi pelaksanaan usahausaha pembangunan daerah dalam rangka Pembangunan Nasional Semesta Berencana.Bank Pembangunan Daerah (BPD) merupakan bagian dari industri perbankan nasional juga harus menunjukkan kinerja efisiensi yang baik untuk mendukung pembangunan daerah (Abidin, 2009).

Bank Pembangunan Daerah (BPD) Syariah merupakan Unit Usaha Syariah (UUS) dari BPD (Fadhlullah, 2015). Terdapat 16 Unit Usaha Syariah yang dibentuk oleh BPD di seluruh Indonesia yang terdaftar pada Bank Indonesia. Perkembangan Unit Usaha Syariah BPD menunjukkan arah peningkatan dari tahun 2012-2016. Peningkatan tersebut dapat dilihat dari aset, pembiayaan dan dana pihak ketiga.

Tabel 1

Perkembangan BPD Syariah Tahun 20122016 (dalam milyar rupiah)

\begin{tabular}{|l|c|c|c|c|c|}
\hline & $\mathbf{2 0 1 2}$ & $\mathbf{2 0 1 3}$ & $\mathbf{2 0 1 4}$ & $\mathbf{2 0 1 5}$ & $\mathbf{2 0 1 6}$ \\
\hline Aset & 11.453 & 14.104 & 17.036 & 19.779 & 22.706 \\
\hline Pembiayaan & 8.297 & 10.801 & 13.072 & 14.753 & 14.503 \\
\hline $\begin{array}{l}\text { Dana Pihak } \\
\text { Ketiga (DPK) }\end{array}$ & 5.957 & 7.547 & 10.781 & 13.179 & 15.772 \\
\hline \multicolumn{7}{|l|}{ Sumber: BPD Syariah, data diolah } \\
\hline
\end{tabular}

Berdasarkan data di atas, diperlukan

evaluasi yang berkaitan dengan pencapaian efisiensi. Hal ini dikarenakan dengan mengetahui tingkat efisiensi UUS, maka diketahui seberapa besar kemampuan UUS BPD dalam mengoptimalkan seluruh sumber daya yang dimilikinya. Pengukuran efisiensi dapat menjadi salah satu indikator penting dalam melihat kemampuan bank untuk bertahan (Firdaus dan Hosen, 2013).

Efisiensi dalam perbankan merupakan salah satu parameter kinerja secara teoritis yang mendasari seluruh kinerja sebuah organisasi. Efisiensi merupakan kemampuan dalam menghasilkan output yang maksimal dengan input yang ada. Analisis mengenai efisiensi menjadi begitu penting karena penghimpunan dan penyaluran pembiayaan yang ekspansif tanpa memperhatikan faktor efisiensi akan berpengaruh pada profitabilitas bank yang bersangkutan (Muharam dan Purvitasari, 2007).

Efisiensi perbankan dapat ditinjau dari dua sudut pandang, yaitu mikro dan makro (Berger dan Mester, 1997).Pada sudut pandang mikro efisiensi perbankan dapat dilihat dari kegiatan operasional bank, yang dapat terlihat dari kinerja keuangan seperti rasio ROA, NPF dann FDR. Pada sudut pandang makro efisiensi dapat dilihat dari tingkat inflasi dan GDP.

$$
\text { Ismail dkk.(2012) menyatakan }
$$
bahwa salah satu indikator efisiensi perbankan adalah Non Performing Financing. Pengukuran efisiensi bank sebagai lembaga intermediasi dapat menggunakan Financing to Deposit Ratio (FDR), yaitu perbandingan antara pembiayaan yang diberikan oleh bank terhadap dana pihak ketiga yang berhasil 
Puspita, et al/ Jurnal Ekonomi Syariah Teori dan Terapan Vol.5 No.10 Oktober 2018: 800-815; DETERMINAN TINGKAT EFISIENSI BANK PEMBANGUNAN DAERAH (BPD) SYARIAH DI INDONESIA: TWOSTAGE DATA ENVELOPMENT ANALYSIS

dihimpun bank. Perhitungan dengan menggunakan rasio Rturn on Asset (ROA), bertujuan untuk mengukur kemampuan manajemen bank dalam memperoleh keuntungan (laba).Ukuran bank atau yang umumnya disebut dengan ukuran perusahaan suatu gambaran yang menunjukkan skala yang mengelompokkan besar kecilnya perusahaan berdasarkan total aset.

Menurut sudut pandang ekonomi islam, konsep efisiensi sejalan dengan prinsip syariah yang bertujuan untuk mencapai dan menjaga salah satu aspek maqashid syariah yaitu terpeliharanya almaal (Kamaruddin, et.al 2008), sebagaimana yang terkandung dalam QS. Al-Isra' (17) ayat 26-27:

Artinya: Dan berikanlah kepada keluargakeluarga yang dekat akan haknya, kepada orang miskin dan orang yang dalam perjalanan dan janganlah kamu menghambur-hamburkan (hartamu) secara boros. Sesunggunnya pemborospemboros itu adalah saudara-saudara syaitan dan syaitan itu adalah sangat ingkar kepada Tuhannya.

Metode yang tepat digunakan untuk menganalisis efisiensi perbankan adalah menggunakan metode parametrik dan non parametrik (Hadad, 2003). Penggunaan metode non parametrik Data Envelopment Analysis menjadi salah satu metode yang paling sering digunakan.

DEA merupakan metode optimasi matematika yang mengukur tingkat efisiensi data Unit Kegiatan Ekonomi (UKE) dan membandingkannya secara relatif terhadap UKE yang lainnya.Pendekatan
DEA memiliki dua model yang sering digunakan, yakni model Constan Return to Scale (CRS) dan Variabel Return to Scale. Hasil perhitungan dengan model CRS disebut juga sebagai efisiensi keseluruhan (overall efficiency), sedangkan hasil perhitungan dengan model VRS disebut juga efisiensi teknik (technical efficincy).

Penelitian mengenai tingkat efisiensi lembaga keuangan terus mengalami perkembangan cukup pesat dan banyak dikaji oleh peneliti, namun sebagian besar hanya fokus pada studi pengukuran efisiensi saja, sehingga tercetuslah suatu prosedur penelitian yang dinamakan TwoStage Data Envelopment Analysis. Prosedur ini dilakukan dua tahap penelitian, tahap pertama dilakukan pengukuran tingkat efisiensi menggunakan metode Data Envelopment Analysis (DEA), selanjutnya pada second stage dilakukan analisis untuk mengetahui faktor-faktor yang mempengaruhi tingkat efisiensi suatu bank menggunakan model Tobit.

Pada penelitian ini akan dilakukan dua tahap penelitian, yang pertama dilakukan pengukuran tingkat efisiensi menggunakan Data Envelopment Analysis dngan asumsi CSR. Variabel yang digunakan dalam proses DEA berdasarkan pendekatan intermediasi, dengan variabel input yaitu dana pihak ketiga (DPK), total aset dan biaya tenaga kerja dan untuk variabel output yaitu pembiayaan dan pendapatan operasional. 
Puspita, et al/ Jurnal Ekonomi Syariah Teori dan Terapan Vol.5 No.10 Oktober 2018: 800-815; DETERMINAN TINGKAT EFISIENSI BANK PEMBANGUNAN DAERAH (BPD) SYARIAH DI INDONESIA: TWOSTAGE DATA ENVELOPMENT ANALYSIS

Tahap selanjutnya adalah menganalisis faktor-faktor apa saja yang mempengaruhi tingkat efisiensi Bank Pembangunan Daerah (BPD) Syariah di Indonesia dengan menggunakan model regresi Tobit. Tahap kedua penggunaan model Tobit, digunakan variabel seperti Ukuran Bank, Retrun On Asset (ROA), Non Performing Financing (NPF), Financing to Deposit Ratio (FDR) dan Inflasi sebagai faktor-faktor yang dapat mempengaruhi efisiensi bank. Metode Tobit mengasumsikan bahwa variabel-variabel bebas tidak terbatas nilainya (noncensured), semua variabel (baik bebas maupun tidak bebas) diukur dengan benar, tidak ada autocorrelation, tidak ada multikolinearitas yang sempurna, dan model matematis yang digunakan menjadi tepat.

Berdasarkan uraian diatas, maka rumusan masalah pada penelitian ini adalah:

1. Apakah tingkat efisiensi Bank Pembangunan Daerah (BPD) Syariah di Indonesia periode 2012-2016 telah mencapai kategori efisien?

2. Apakah variabel Ukuran Bank, ROA, NPF, FDR dan Inflasi mempengaruhi tingkat efisiensi Bank Pembangunan Daerah (BPD) Syariah di Indonesia Periode 2012-2016?

Tujuan yang ingin dicapai adalah untuk mengetahui tingkat efisiensi BPD Syariah di Indonesia periode 2012-2016 telah mencapai kategori efisien, serta mengetahui variabel Ukuran Bank, ROA,
NPF, FDR dan Inflasi mempengaruhi tingkat efisiensi Bank Pembangunan Daerah (BPD) Syariah di Indonesia periode 2012-2016.

\section{LANDASAN TEORI}

Bank Pembangunan Daerah (BPD) adalah bank yang didirikan di Daerah Swatantra Tingkat I yang dimaksudkan untuk menyediakan pembiayaan bagi pelaksanaan usaha-usaha pembangunan daerah dalam rangka Pembangunan Nasional Semesta Berencana (UU No. 13 tahun 1962).Tujuan awal didirikannya Bank Pembangunan Daerah adalah untuk mengemban misi publik, dengan demikian orientasi profit tidak menjadi fokus Bank Pembangunan Daerah.

Berlakunya Undang-Undang No. 10 tahun 1998 tentang Perbankan dan Undang-Undang No. 23 tahun 1999 tentang Bank Indonesia yang menegaskan bahwa Bank Indonesia mempersiapkan perangkat aturan dan fasilitas penunjang yang mendukung operasional Bank Syariah.Berlakunya undang-undang tersebut membuat Bank Pembangunan Daerah yang bertujuan sebagai agent of development mendirikan unit layanan berbasis syariah.

Bank Pembangunan Daerah (BPD) Syariah merupakan Unit Usaha Syariah dari Bank Pembangunan Daerah (Fadhlullah, 2015:2).Menurut data dari Bank Indonesia dari 26 jumlah Bank Pembangunan Daerah, hanya terdapat 16 Unit Usaha Syariah (UUS) yang dibentuk dari BPD yang tersebar di seluruh wilayah Indonesia. 
Puspita, et al/ Jurnal Ekonomi Syariah Teori dan Terapan Vol.5 No.10 Oktober 2018: 800-815; DETERMINAN TINGKAT EFISIENSI BANK PEMBANGUNAN DAERAH (BPD) SYARIAH DI INDONESIA: TWOSTAGE DATA ENVELOPMENT ANALYSIS

Lahirnya Unit Usaha Syariah (UUS)

pada Bank Pembangunan Daerah sebagai salah satu solusi alternatif terhadap persoalan pertentangan antara bunga bank dengan riba, sama seperti halnya lahirnya Bank Umum Syariah. Adanya UUS pada Bank Pembangunan Daerah ini diharapkan mampu memberikan sumbangan terhadap pertumbuhan ekonomi masyarakat melalui pembiayaan-pembiayaan yang aman.

Efisiensi merupakan aspek yang sangat penting diperhatikan untuk mewujudkan suatu kinerja keuangan yang sehat dan berkelanjutan (sustainable). Wheelock dan Wilson (1999) berpendapat bahwa efisien adalah ukuran penting dari kondisi operasional bank dan merupakan salah satu kunci indikator pencapaian kinerja individual bank, setelah membandingkan dengan kinerja seluruh industri perbankan. Efisiensi juga didefinisikan sebagai perbandingan antara keluaran (output) dengan masukan (input), atau jumlah yang dihasilkan dari satu input yang digunakan (Permono dan Darmawan, 2000:2).

Efisiensi perbankan merupakan suatu tolak ukur dalam mengukur kinerja bank, dimana efisiensi sebagai alat dalam menghitung ukuran-ukuran kinerja seperti tingkat alokasi, teknis, maupun total efisien (Hadad. dkk, 2003:6).Efisiensi perbankan pada dasarnya memiliki kesamaan dengan efisiensi perusahaan lainnya, khususnya perusahaan yang melakukan proses produksi (Begum, 2015:38). Perusahaan yang melakukan produksi pastinya akan sangat memperhatikan masalah efisiensi, karena semakin perusahaan tersebut efisien dalam proses produksi maka akan semakin besar keuntungan yang akan didapat, dan begitu pula pada perbankan.

Efisiensi merupakaan hal yang sangat penting dan perlu untuk mendapatkan perhatian agar perbankan syariah dapat berdaya saing, berkembang dan mampu berperan secara lebih optimal bagi pembangunan nasional.Konsep efisiensi pada dasarnya adalah menghindari segala bentuk pemborosan sebagaimana terkandung dalam QS.Al-Israa' ayat 26-27.

Konsep efisiensi dalam pandangan Islam adalah kemampuan suatu entitas bisnis (bank) untuk memperolah output semaksimal mungkin dari sejumlah input tertentu dengan menggunakan cara-cara yang halal dan toyyib (baik). sesuai dengan firman Allah SWT dalam surat AlBaqarah (2) ayat 168:

Artinya: Hai sekalian manusia, makanlah yang halal lagi baik dari apa yang terdapat di bumi, dan janganlah kamu mengikuti langkah-langkah syaitan; karena Sesungguhnya syaitan itu adalah musuh yang nyata bagimu. (QS. AlBaqarah (2) ayat 168).

Ukuran bank (size) adalah suatu skala yang mengelompokkan besar kecilnya perusahaan berdasarkan berbagai cara yaitu dengan total aset, total penjualan atau total modal (Basyaib, 2007:122). Semakin besar suatu bank 
Puspita, et al/ Jurnal Ekonomi Syariah Teori dan Terapan Vol.5 No.10 Oktober 2018: 800-815; DETERMINAN TINGKAT EFISIENSI BANK PEMBANGUNAN DAERAH (BPD) SYARIAH DI INDONESIA: TWOSTAGE DATA ENVELOPMENT ANALYSIS

maka semakin besar total aset yang dimiliki, hal ini menunjukkan bank dapat menjalankan kegiatan operasionalnya menjadi lebih leluasa. Menurut Ismail dkk. (2012) dan Fathony (2012), ukuran suatu bank mempunyai pengaruh yang positif dan signifikan terhadap efisiensi.Bank yang memiliki aset yang besar juga akan lebih mudah mengadopsi perkembangan teknologi baru yang dapat meningkatkan keuntungan dan meminimalkan biaya.

Mishkin (2010:451) mengatakan bahwa bank harus mengetahui apakah banktersebut telah berjalan dengan baik atau tidak, dengan melihat rasio profitabilitas bank yangtergambar dari ROA. Return On Asset merupakan indikator penting karena para pemegang saham dan calon investor akan mengukur sejauh mana kemampuan bank dalam memperoleh laba bersih yang akan dikaitkan dengan pembayaran deviden. ROA yang mewakili tingkat profitabilitas menunjukkan besarnya keuntungan bersih yang didapat bank dibandingkan dengan nilai aset yang dikuasai.Semakin tinggi ROAyang dimiliki menunjukkan bahwa bank dapat menghasilkan keuntungan yang lebih besar, dan mengindikasikan bahwa bank lebih efisiensi. Firdaus dan Hosen (2013)menyatakan bahwa ROA memiliki hubungan yang positif dan signifikan terhadap tingkat efisiensi.

Non Performing Financing
merupakan salah satu rasio yang
mengukur risiko yang ditanggung oleh
bank karena nasabah tidak sanggup

untuk membayar pembiayaan yang diberikan. Bank dengan jumlah pembiayaan macet yang tinggi tidak akan beroperasi secara efisien. Semakin tinggi rasio NPF akan menggangu kegiatan operasional bank, terutama pada sisi likuiditas bank.NPF yang tinggi akan memperburuk kualitas pembiayaan dan akan menambah jumlah pembiayaan bermasalah semakin besar, hal tersebut berdampak pada penurunan laba bank. Firdaus dan Hosen (2013) menyatakan NPF memiliki pengaruh yang negatif dan signifikan terhadap efisiensi bank, namun hasil berbeda ditunjukkan oleh Ramly (2015) yang memperlihatkan adanya pengaruh positif dan signifikan antara NPF terhadap tingkat efisiensi.

Financing to Deposit Ratio mencerminkan besarnya alokasi pembiayaan dari dana yang dihimpun dari masyrakat (Pambuko, 2016). Sufian dan Noor (2009) mengungkapkan semakin besar pembiayaan yang disalurkan, akan membuat bank lebih efisien.Kenaikan FDR akan meningkatkan retrun sehingga kinerja keuangan bank akan semakin baik dan bank menjadi lebih efisien.

Inflasi dapat diartikan sebagai peningkatan tingkat harga secarakeseluruhan dalam suatu perekonomian (Mankiw, 2004:425). Laju inflasi yang tinggi dan tidak terkendali dapat menggangguupaya perbankan dalam pengerahan daya masyarakat untuk menabung karena tingkat inflasi yang tinggi. Sufian dan Habibullah (2010), 
Puspita, et al/ Jurnal Ekonomi Syariah Teori dan Terapan Vol.5 No.10 Oktober 2018: 800-815; DETERMINAN TINGKAT EFISIENSI BANK PEMBANGUNAN DAERAH (BPD) SYARIAH DI INDONESIA: TWOSTAGE DATA ENVELOPMENT ANALYSIS

serta Noor dan Ahmad (2011) mengungkapkan bahwa inflasi tidak memberikan pengaruh yang nyata terhadap tingkat efisiensi bank.

Pendekatan DEA pertama kali dikemukakan oleh Charnes, Chooper dan Rhodes pada tahun 1978. Tujuan dari metode DEA adalahmengukur tingkat efisiensi dari Decision Making Unit (DMU) relatif terhadap bank yang sejenis. Teknik DEA menciptakan batasan yang ditetapkan oleh bank-bank yang efisien dan membandingkannya dengan bankbank yang tidak efisien untuk menghasilkan nilai efisiensi (Yudistira, 2004:4).

Terdapat dua model yang digunakan dalam pendekatan DEA, yaitu model CRS dan VRS.Model Constant Return to Scalemengasumsikan bahwa dalam model ini setiap DMU beroperasi pada skala optimal, sehingga perubahan proporsional pada input akan menghasilkan perubahan yang proporsional yang sama pada tingkat output. Model VRS merupakan pengembangan dari model CRS. Variabel Return to Scale mengasumsikan bahwa DMU belum berada pada keadaan yang optimal, sehingga setiap penambahan input tidak sama dengan penambahan output.

Model yang digunakan dalam penelitian ini mengacu pada model yang disusun oleh Faza dan Hosen (2013) untuk mengukur tingkat efisiensi digunakan metode Data Envelopment Analysis (DEA) dengan menggunakan asumsi Constant Return to Scale (CRS) berkenaan dengan peranan bank sebagai lembaga intermediasi. Variabel input yang digunakan dalam penelitian ini meliputi dana pihak ketiga atau DPK $\left(l_{1}\right)$, total aset $\left(I_{2}\right)$, dan biaya tenaga kerja $\left(I_{3}\right)$. Untuk variabel output yang digunakan adalah pembiayaan $\left(\mathrm{O}_{1}\right)$ dan pendapatan operasional $\left(\mathrm{O}_{2}\right)$.

Model ini pertama kali ditemukan oleh James Tobin pada tahun 1958. Metode Tobit mengasumsikan bahwa variabel-variabel bebas tidak terbatas nilainya (non-censured), hanya variabel tidak bebas yang censured. Tobit juga mengasumsikan bahwa semua variabel (baik bebas dan tidak bebas) diukur dengan benar, tidak terdapat autokorelasi, tidak ada heteroscedascity, tidak ada multikolinearitas yang sempurna dan model matematis yang digunakan tepat.

Model analisis tahap kedua yang digunakan untuk menguji pengaruh Ukuran Bank, Return On Asset (ROA), Non Performing Financing (NPF), Financing to Deposit Ratio (FDR) dan Inflasi terhadap efisiensi Bank Pembangunan Daerah (BPD) Syariah adalah regresi Tobit.

Penggunaan metode Tobit pada penelitian ini dikarenakan data yang digunakan dalam penelitian ini merupakan data yang censored, yaitu nilai dari variabel tidak bebas dalam hal ini tingkat efisiensi Bank Pembangunan Daerah (BPD) Syariah yang dibatasi dan 
Puspita, et al/ Jurnal Ekonomi Syariah Teori dan Terapan Vol.5 No.10 Oktober 2018: 800-815; DETERMINAN TINGKAT EFISIENSI BANK PEMBANGUNAN DAERAH (BPD) SYARIAH DI INDONESIA: TWOSTAGE DATA ENVELOPMENT ANALYSIS

hanya boleh berkisar antara nol sampai satu.

Berdasarkan latar belakang, rumusan masalah, tujuan penelitian dan landasan toeri maka hipotesis dalam penelitian ini adalah:

$H_{1}$ : Ukuran Bank berpengaruh signifikan terhadap efisiensi Bank Pembangunan Daerah (BPD) Syariah di Indonesia.

$\mathrm{H}_{2}$ : ROA berpengaruh signifikan terhadap efisiensi Bank Pembangunan Daerah (BPD) Syariah di Indonesia.

$\mathrm{H}_{3}$ : NPF berpengaruh signifikan terhadap efisiensi Bank Pembangunan Daerah (BPD) Syariah di Indonesia.

$\mathrm{H}_{4}$ : FDR berpengaruh signifikan terhadap efisiensi Bank Pembangunan Daerah (BPD) Syariah di Indonesia.

$\mathrm{H}_{5}$ : Inflasi tidak berpengaruh signifikan terhadap efisiensi Bank Pembangunan Daerah (BPD) Syariah di Indonesia.

\section{METODE PENELITIAN}

Penelitian ini menggunakan pendekatan kuantitatif. Sugiyono (2003:14) menjelaskan pendekatan kuantitatif adalah pendekatan yang memiliki fokus utama dalam pengujian hipotesis, data yang dianalisis sifatnya terukur akan menghasilkan kesimpulan yang dapat digeneralisasikan.

Untuk menjawab rumusan masalah dan menguji hipotesis, maka variabel dependen yang digunakan adalah nilai efisiensi dari hasil pengukuran DEA.Variabel input untuk mengukur tingkat efisiensi menggunakan metode DEA pada first stage pendekatan intermediasi adalahDana Pihak Ketiga $\left(l_{1}\right)$, Total Aset ( $\left.I_{2}\right)$ dan Biaya Tenaga Kerja ( $\left.I_{3}\right)$, sedangkanvariabel outputnya adalah Pembiayaan $\left(\mathrm{O}_{1}\right)$ dan Pendapatan Operasional $\left(\mathrm{O}_{2}\right)$.

Variabel independen yang digunakan adalah Ukuran Bank ( $\left.X_{1}\right)$, Return On Asset $\left(X_{2}\right)$, Non Performing Financing $\left(X_{3}\right)$, Financing to Deposit Ratio $\left(X_{4}\right)$ dan Inflasi $\left(X_{5}\right)$ untuk menganalisis faktor-faktor yang mempengaruhi efisiensi Bank Pembangunan Daerah (BPD) Syariah dengan menggunakan regresi Tobit.

Definisi operasional yang digunakan dalam penelitian ini meliputi:

1. Dana Pihak Ketiga (l1) dapat disebut juga dana masyarakat, karena dana diperoleh dari masyarakat sebagai individu, perusahaan, pemerintah, rumah tangga, sekolah, yayasan, dan lain sebagainya dalam bentuk rupiah atau mata vang asing. Perhitungan dana pihak ketiga dalam penelitian ini didapat dari penjumlahan banyaknya dana simpanan wadiah atau giro wadiah, tabungan dan deposito mudharabah yang dihimpun bank, yang dilihat pada laporan neraca dalam laporan keuangan tahunan BPD Syariah bersangkutan selama periode pengamatan, yakni tahun 2012-2016.

2. Total Aset ( $\left.I_{2}\right)$ adalah kekayaan atau sumber daya yang dimiliki oleh suatu perusahaan. Total aset penelitian ini 
Puspita, et al/ Jurnal Ekonomi Syariah Teori dan Terapan Vol.5 No.10 Oktober 2018: 800-815; DETERMINAN TINGKAT EFISIENSI BANK PEMBANGUNAN DAERAH (BPD) SYARIAH DI INDONESIA: TWOSTAGE DATA ENVELOPMENT ANALYSIS

didapat dari penjumlahan dari aset lancar dan tidak lancar yang dilihat pada laporan neraca dalam laporan keuangan tahunan BPD Syariah yang bersangkutan selama periode 20122016.

3. Biaya tenaga kerja $\left(l_{3}\right)$ merupakan biaya yang dikeluarkan untuk membayar para pegawai yang bekerja pada suatu perusahaan. Biaya tenaga kerja diperoleh dari laporan laba/rugi dalam laporan keuangan tahunan BPD Syariah yang bersangkutan selama periode 20122016.

4. Pembiayaan $\left(O_{1}\right)$ adalah penyediaan vang atau tagihan yang dipersamakan dengan itu berdasarkan persetujuan atau kesepakatan antara bank dengan pihak ketiga yang mewajibkan pihak ketiga yang dibiayai tersebut untuk mengembalikan vang atau tagihan tersebut dalam jangka waktu tertentu dengan imbalan atau bagi hasil (Siamat, 2001:183). Pada penelitian ini digunakan pembiayaan berdasarkan prinsip murabahah, mudharabah, musyarakah dan ijarah yang diperoleh dari laporan neraca dalam laporan keuangan tahunan BPD Syariah.

5. Pendapatan operasional adalah semua pendapatan yang diperoleh dari kegiatan utama bank. Pendapatan operasional pada penelitian ini adalah pendapatan dari penyaluran dana yang diperbolehkan syariah yaitu pendapatan atas penyaluran dana dengan prinsip jual beli (murabahah), pendapatan dari penyaluran bagi hasil (mudharabah dan musyarakah) dan pendapatan dari ujroh (bonus), serta pendapatan atas penyaluran dana lainnya sesuai prinsip Islam yang dapat diperoleh dari laporan laba/rugi dalam laporan keuangan tahunan BPD Syariah

6. Ukuran bank $\left(X_{1}\right)$ mencerminkan total aset yang dimiliki suatu bank. Pada penelitian ini rumus yang digunakan untuk mengukur ukuran bank adalah logaritma natural dari total aset.

7. Retrun On Asset ( $\left.\mathrm{X}_{2}\right)$ adalah salah satu rasio profitabilitas yang mengukur kemampuan bank dalam menghasilkan laba dengan menggunakan total aktiva.ROA diperoleh dengan membagi laba bersih sebelum pajak dengan jumlah aktiva yang dimiliki bank, yang didapat dari laporan kevangan BPD Syariah.

8. Non Performing Financing $\left(\mathrm{X}_{3}\right)$ digunakan untuk mengukur tingkat pembiayaan bermasalah yang dihadapi oleh bank.Pada penelitian ini rasio NPF didapat dari NPF gross pada rasio kevangan yang terdapat pada laporan keuangan per Desember BPD Syariah.

9. Financing to Deposit Ratio $\left(X_{4}\right)$ merupakan perbandingan antara pembiayaan yang diberikan oleh bank dengan dana pihak ketiga. 
Puspita, et al/ Jurnal Ekonomi Syariah Teori dan Terapan Vol.5 No.10 Oktober 2018: 800-815; DETERMINAN TINGKAT EFISIENSI BANK PEMBANGUNAN DAERAH (BPD) SYARIAH DI INDONESIA: TWOSTAGE DATA ENVELOPMENT ANALYSIS

Pada penelitian ini untuk financing digunakan pembiayaan berdasarkan prinsip murabahah, mudharabah, musyarakah dan ijarah, sedangkan untuk deposit digunakan giro wadiah, tabungan dan deposito mudharabah.

10. Weston dan Copeland (1998:250) mendefinisikan Inflasi $\left(X_{5}\right)$ sebagai suatu keadaan ekonomi yang mengalami kenaikan tingkat harga tertinggi dan tidak dapat dicegah atau dikendalikan lagi. Data inflasi yang digunakan dalam penelitian ini menggunakan inflasi tahunan yang diambil dari Badan Pusat Statistik www.bps.go.id periode 2012-2016.

Jenis data yang digunakan dalam penelitian ini adalah data sekunder, yaitu data yang diperoleh peneliti tidak secara langsung dari obyek penelitianmelainkan melalui laporan kevangan Bank Pembangunan Daerah (BPD) Syariah yang telah dipublikasikan oleh Bank Indonesia periode 2012-2016.Langkah selanjutnya dilakukan pengumpulan pustaka dengan mengkaji buku-buku literatur, jurnal, makalah dan internet untuk memperoleh landasan teori serta bagaimana perkembangan Bank Pembangunan Daerah (BPD) Syariah untuk mendukung penelitian.

Populasi dalam penelitian ini adalah Bank Pembangunan Daerah Syariah yang terdaftar dalam Bank Indonesia pada tahun 2012 hingga akhir tahun 2016.Teknik pengambilan sampel dalam penelitian ini menggunakan teknik purposive sampling, dimana dalam penelitianini sampel yang digunakanadalah Bank Pembangunan Daerah yang memiliki Unit Usaha Syariah (UUS) yang terdaftar pada Bank Indonesia periode 2012-2016, selama periode penelitian bank menyajikan secara lengkap laporan keuangan dari tahun 2012-2016 dan telah dipublikasikanserta tidak mengalami perubahan bentuk badan usaha. Berdasarkan kriteria tersebut, didapat 14 Unit Usaha Syariah (UUS) dari Bank Pembangunan Daerah (BPD) yang menjadi sampel penelitian.

Teknik analisis data pada penelitian ini menggunakan Data Envelopment Analysis (DEA) dengan pendekatan intermediasi serta analisis regersi model Tobit. Pada tahap pertama (first stage) digunakan uji statistik non-parametrik DEA dengan asumsi Constant Return to Scale (CRS) berorintasi input. Orientasi input dipilih dikarenakan fokus utama Bank Pembangunan Daerah (BPD) sendiri adalah untuk pembangunan daerah bukan pada memperoleh banyak keuntungan, hal ini sesuai dengan tujuan didirikannya BPD. Tahapan pengukuran DEA yaitu melakukan pengumpulan datadata yaitu pemilihan DMU, setelah itu dilakukan identifikasi variabel input dan output kemudian mengolahnya dengan bantuan software DEAP ver. 2.1. untuk memperoleh tingkat efisiensi masingmasing DMU. DMU dengan nilai efisiensi 1 dikatakan efisien, apabila nilai kurang dari 1 DMU dikatakan inefisien. 
Puspita, et al/ Jurnal Ekonomi Syariah Teori dan Terapan Vol.5 No.10 Oktober 2018: 800-815; DETERMINAN TINGKAT EFISIENSI BANK PEMBANGUNAN DAERAH (BPD) SYARIAH DI INDONESIA: TWOSTAGE DATA ENVELOPMENT ANALYSIS

$\begin{array}{clll}\text { Tahap } & \text { selanjutnya } & \text { untuk } & \text { signifikasi terendah pada masing-masing } \\ \text { menganalisis } & \text { faktor-faktor } & \text { yang } & \text { variabel independen. }\end{array}$
mempengaruhi tingkat efisiensi Unit Usaha Syariah pada Bank Pembangunan Daerah, digunakan regresi Tobit. Tahapan ini adalah meregresi nilai efisiensi UUS BPDhasil proses DEA dengan variabel independen yang telah dijelaskan sebelumnya. Perhitungan model Tobit menggunakan software Eviews 8.1.

Persamaan regresi Tobit dalam penelitian ini adalah sebagai berikut:

$Y=\beta+\beta_{1}$ (Size) $+\beta_{2}(\mathrm{ROA})+\beta_{3}(\mathrm{NPF})+\beta_{4}$ $(F D R)+\beta_{5}\left(\right.$ Inflasi) $+\varepsilon_{i}$

Y merupakan variabel terikat (dependen) yang merupakan tingkat efisiensi Bank Pembangunan Daerah Syariah di Indonesia hasil dari pengukuran DEA.

Mengetahui apakah variabel independen berpengaruh secara signifikan terhadap variabel dependen dalam model tobit, maka akan dilakukan uji hipotesis pada level signifikan 5\% (a = 0,05), sebagai berikut:

$H_{0}=\beta_{1}, \beta_{2}, \beta_{3}, \beta_{4}, \beta_{5}=0$

$H_{1}=\beta_{1}, \beta_{2}, \beta_{3}, \beta_{4}, \beta_{5} \neq 0$

Ho menjelaskan bahwa variabel independen tidak memiliki pengaruh terhadap efisiensi Unit Usaha Syariah pada $B P D$, sedangkan $H_{1}$ menjelaskan bahwa variabel independen memiliki pengaruh terhadap efisiensi Unit Usaha Syariah pada BPD. Terdapat cara lain dalam menentukan adanya penerimaan ataupun penolakan hipotesis, yaitu dengan menggunakan p-value (Gujarati, 2003:137). P-value merupakan level

\section{HASIL PENELITIAN DAN PEMBAHASAN}

Hasil dari perhitungan tingkat efisienai dalam metode DEA memiliki skor nol hingga satu. Unit Usaha Syariah BPD yang memiliki skor satu dinyatakan efisien, yang berarti UUS memiliki kemampuan dalam mengoptimalkan seluruh sumber daya yang dimilikinya, sebaliknya apabila UUS memiliki skor nol hingga kurang dari satu, UUS dinyatakan inefisien dalam mengoptimalkan sumber daya yang dimilikinya dan belum mampu menjalankan perannya sebagai lembaga intermediasi secara optimal. Pengukuran nilai efisiensi pada Unit Usaha Syariah (UUS) yang dimiliki oleh Bank Pembangunan Daerah (BPD) di Indonesia ini melibatkan 14 DMU sampel.

Pada Tabel 2terlihat pencapaian tingkat efisiensi masing-masing UUS dalam rentang waktu 2012-2016. Terdapat enam dari empat belas DMU Unit Usaha Syariah yang dimiliki BPD di Indonesia yang sedikitnya sekali dinyatakan efisien atau dapat berarti $42,86 \%$ UUS BPD secara relatif dinyatakan efisien atau mencapai Overall Technical Efficiency.

Tabel 2. menunjukkan terdapat Unit Usaha Syariah yang relatif stabil mengalami efisiensi dari tahun 2012-2016 yang meliputi UUS Bank DKI, UUS Bank Jambi, UUS Bank Kalimantan Barat, UUS Bank Sumatera Barat dan UUS Bank Sulawesi Selatan Sulawesi Barat. Kelima UUS tersebut dapat dijadikan acuan bagi 
Puspita, et al/ Jurnal Ekonomi Syariah Teori dan Terapan Vol.5 No.10 Oktober 2018: 800-815; DETERMINAN TINGKAT EFISIENSI BANK PEMBANGUNAN DAERAH (BPD) SYARIAH DI INDONESIA: TWOSTAGE DATA ENVELOPMENT ANALYSIS

UUS lainnya yang belum mencapai tingkat efisiensi.

Tabel 2

Hasil Efisiensi Unit Usaha Syariah pada BPD Tahun 2012-2016

\begin{tabular}{|l|r|r|r|r|r|}
\hline \multirow{2}{*}{\multicolumn{1}{|c|}{ DMU }} & \multicolumn{5}{|c|}{ Tingkat Efisiensi } \\
\cline { 2 - 6 } & $\mathbf{2 0 1 2}$ & $\mathbf{2 0 1 3}$ & $\mathbf{2 0 1 4}$ & $\mathbf{2 0 1 5}$ & $\mathbf{2 0 1 6}$ \\
\hline UUS Bank DKI & 1 & 1 & 1 & 1 & 1 \\
\hline UUS Bank DIY & 0,708 & 0,734 & 0,834 & 0,714 & 0,852 \\
\hline UUS Bank Jatim & 0,793 & 0,806 & 0,490 & 0,544 & 0,482 \\
\hline UUS Bank Jateng & 0,456 & 0,521 & 0,803 & 0,705 & 0,504 \\
\hline UUS Bank Jambi & 1 & 1 & 1 & 1 & 1 \\
\hline UUS Bank Riau & 0,720 & 0,880 & 0,840 & 1 & 0,992 \\
\hline UUS Bank Kaltim & 0,459 & 0,755 & 0,757 & 0,660 & 0,588 \\
\hline UUS Bank Kalbar & 1 & 1 & 1 & 1 & 1 \\
\hline UUS Bank Kalsel & 0,683 & 0,739 & 0,756 & 0,801 & 0,816 \\
\hline UUS Bank Sumbar & 1 & 1 & 1 & 1 & 1 \\
\hline $\begin{array}{l}\text { UUS Bank Sumsel } \\
\text { dan Babel }\end{array}$ & 0,729 & 0,626 & 0,699 & 0,557 & 0,646 \\
\hline UUS Bank Sumut & 0,867 & 0,995 & 0,906 & 0,933 & 0,869 \\
\hline $\begin{array}{l}\text { UUS Bank SUlsel } \\
\text { SUlbar }\end{array}$ & 1 & 1 & 1 & 1 & 1 \\
\hline UUS Bank NTB & 0,996 & 0,695 & 0,654 & 0,690 & 0,781 \\
\hline Rata-rata & 0,815 & 0,839 & 0,839 & 0,829 & 0,824 \\
\hline Tertinggi & 1 & 1 & 1 & 1 & 1 \\
\hline Terendah & 0,456 & 0,521 & 0,490 & 0,544 & 0,482 \\
\hline SUmber: aata
\end{tabular}

Sumber: data diolah dari software DEAP 2.1

Pada Tabel tersebut dapat dijelaskan bahwa efisiensi Unit Usaha Syariah (UUS) pada Bank Pembangunan Daerah (BPD) di Indonesia periode 20122016 masih dalam kategori inefisien. Hal ini terlihat bahwa selama periode penelitian skor rata-rata efisiensi UUS yang tertinggi dicapai pada tahun 2013-2014 dengan skor sebesar 0,839 atau setara $83,9 \%$ dan skor terendah pada tahun 2012 dengan capaian skor sebesar 0,815 atau $81,5 \%$. Hasil dari pengukuran tingkat efisiensi tersebut menandakan bahwa Unit Usaha Syariah (UUS) BPD belum mampu untuk mengelola sumber daya yang dimilikinya secara optimal. Hal ini sejalan dengan hasil penelitian yang dilakukan oleh Rabbani (2014), Fadhlullah (2015) dan
Ramly (2015) yang menyatakan bahwa Unit Usaha Syariah (UUS) Bank Pembangunan Daerah belum mampu beroperasi secara optimal.

Tahap selanjutnya penelitian ini adalah menganalisis faktor-faktor yang mempengaruhi tingkat efisiensi Unit Usaha Syaria (UUS) pada Bank Pembangunan Daerah (BPD) di Indonesia periode 20122016 dengan menggunakan model Tobit. Hasil analisis Tobit dengan menggunakan software Eviews 8.1 ini dapat dilihat pada Tabel 3 yang menunjukkan terdapat beberapa variabel seperti variabel Ukuran Bank, Return On Asset (ROA) dan Financing to Deposit Ratio (FDR) bersifat positif dan memiliki nilai $p$-value lebih kecil dari nilai a ( $p$-value <0,05) sehingga membuat variabel-variabel tersebut berpengaruh secara signifikan terhadap tingkat efisiensi UUS. Variabel Non Performing Financing memiliki hubungan positif terhadap tingkat efisiensi UUS, sedangkan pada variabel Inflasi memiliki pengaruh yang negatif, namun kedua variabel tersebut memiliki nilai $p$-value yang lebih besar dari nilai a yang digunakan peneliti, sehingga kedua variabel tersebut tidak memiliki pengaruh terhadap tingkat efisiensi UUS dalam penelitian ini.

Berdasarkan hasil model Tobit pada Tabel 3, dapat dijelaskan bahwa variabel Ukuran Bank memiliki koefisien regresi sebesar 0,054204 yang artinya apabila variabel ukuran bank meningkat sebesar satu persen (1\%) makan akan 
Puspita, et al/ Jurnal Ekonomi Syariah Teori dan Terapan Vol.5 No.10 Oktober 2018: 800-815; DETERMINAN TINGKAT EFISIENSI BANK PEMBANGUNAN DAERAH (BPD) SYARIAH DI INDONESIA: TWOSTAGE DATA ENVELOPMENT ANALYSIS

meningkatkan efisiensi UUS BPD sebesar 0,054204 persen.

\section{Tabel 3}

Hasil Analisis Regresi Tobit

\begin{tabular}{ccccc}
\hline Variable & Coefficient & Std. Error & z-Statistic & Prob. \\
\hline \hline Ukuran Bank & 0.054204 & 0.025162 & 2.154206 & 0.0312 \\
ROA & 0.052937 & 0.010142 & 5.219405 & 0.0000 \\
NPF & 0.008345 & 0.004796 & 1.739951 & 0.0819 \\
FDR & 0.000702 & 0.000168 & 4.169093 & 0.0000 \\
Inflasi & -0.005094 & 0.006790 & -0.750264 & 0.4531 \\
C & -0.166413 & 0.356583 & -0.466688 & 0.6407 \\
\hline \hline
\end{tabular}

Sumber: Hasil olah data Eviews 8.

Variabel Return On Asset memiliki nilai koefisien regresi sebesar 0,052937 hal tersebut menandakan bahwa apabila variabel ROA meningkat sebesar satu persen (1\%) maka akan meningkatkan efisiensi sebesar 0,052937 persen. Pada variabel Non Performing Financing (NPF) memiliki koefisien regresi sebesar 0,008345 hal ini menandakan bahwa apabila variabel NPF meningkat sebesar satu persen (1\%) maka akan meningkatkan efisiensi UUS BPD sebesar 0,008345 persen. Variabel Financing to Deposit Ratio memiliki koefisien regresi sebesar 0,000702 hal ini menandakan bahwa apabila variabel FDR meningkat sebesar satu persen (1\%) maka akan meningkatkan efisiensi UUS BPD sebesar 0,000702 persen.

Hasil penelitian melalui model Tobit diperoleh nilai p-value variabel Ukuran Bank sebesar 0,0312 (0,0312<0,05), sehingga hipotesis pertama $\left(\mathrm{H}_{1}\right)$ diterima. Variabel ukuran bank memiliki pengaruh positif dan signifikan, sehingga dapat dijelaskan bahwa varuabel ukuran bank memiliki pengaruh yang nyata terhadap tingkat efisiensi Unit Usaha Syariah pada Bank Pembangunan Daerah (BPD) di Indonesai periode 2012-2016. Bank yang memiliki jumlah aset yang besar akan membuat bank tersebut menjadi lebih efisien dikarenakan dengan banyaknya total aset yang dimiliki akan membantu kelancaran kegiatan operasional bank.Semakin banyak jumlah aset yang dimiliki juga akan memperluas pangsa pasar dari UUS BPD. Hasil dari penelitian ini sesuai dengan penelitian terdahulu yang dilakukan oleh Firdaus dan Hosen (2013).

Hasil penelitian pada variabel Retrun On Asset diperoleh nilai $p$-value sebesar $0,0000(0,0000<0,05)$, sehingga hipotesis kedua $\left(\mathrm{H}_{2}\right)$ diterima. Pada variabel ROA memiliki tanda yang positif, hal ini menjelaskan bahwa variabel ROA memiliki pengaruh yang nyata terhadap tingkat efisiensi Unit Usaha Syariah pada Bank Pembangunan Daerah (BPD) di Indonesai periode 2012-2016. Return On Asset merupakan kemampuan dari modal yang diinvestasikan dalam seluruh aset perusahaan guna menghasilkan keuntungan (Pambuko, 2016).Semakin tinggi rasio ROA maka UUS BPD mampu menghasilkan tingkat keuntungan yang besar, sehingga UUS akan dikategorikan sebagai UUS yang efisien. Hasil penelitian ini sesuai dengan penelitian yang dilakukan oleh Yudistira (2004), dan Firdaus dan Hosen (2013).

Berdasarkan hasil pengujian analisis model Tobit menunjukkan variabel Non Performing Financing memiliki hubungan 
Puspita, et al/ Jurnal Ekonomi Syariah Teori dan Terapan Vol.5 No.10 Oktober 2018: 800-815; DETERMINAN TINGKAT EFISIENSI BANK PEMBANGUNAN DAERAH (BPD) SYARIAH DI INDONESIA: TWOSTAGE DATA ENVELOPMENT ANALYSIS

positif dengan $p$-value lebih besar dari $0,05 \cdot(0,0819>0,05)$, sehingga hipotesis ketiga $\left(\mathrm{H}_{3}\right)$ ditolak. Hasil dari penelitian ini tidak mendukung hasil penelitian dari Firdaus dan Hosen (2013) yang mengunkapkan bahwa NPF berpengaruh negatif signifikan terhadap tingkat efisiensi, dikarenakan semakin besar rasio pembiayaan macet akan mengganggu operasional bank. Hasil yang berbeda dikemukakan oleh Pambuko (2016) yang mengungkapkan NPF berpengaruh positif dan signifikan $(<0,05)$ terhadap efisiensi perbankan syariah. Penelitian yang dilakukan oleh Ramly (2015) juga mengatakan hal yang sama dengan mengungkapkan bahwa NPF berpengaruh positif signifikan, dan menyatakan kenaikan rasio NPF akan menaikkan tingkat efisiensi BPD konvensional dan UUS BPD. Hubungan positif ini dapat dijelaskan dengan teori yang dikemukakan Berger dan Humphrey (1997) dalam Fathony (2012) yang disebut skimping hypothesis, dengan asumsi bank menerapkan kebijakan pembatasan pengeluran untuk melakukan analisis terhadap aplikasi pembiayaan.

Hasil penelitian pada variabel FDR diperoleh nilai p-value sebesar 0,0000 $(0,0000<0,05)$, sehingga hipotesis keempat $\left(\mathrm{H}_{4}\right)$ diterima. Nilai koefisien pada variabel FDR juga memiliki tanda positif dan dapat dijelaskan bahwa variabel FDR memiliki pengaruh yang nyata terhadap tingkat efisiensi Unit Usaha Syariah pada Bank Pembangunan Daerah
(BPD) di Indonesai periode 2012-2016. Hal tersebut dikarenakan semakin banyak porsi dana pihak ketiga yang disalurkan Unit Usaha Syariah untuk pembiayaan akan menjadikan UUS semakin efisien dalam mengelola sumber dayanya.Hasil penelitian ini sesuai dengan penelitian terdahulu yang dilakukan oleh Sufian dan Noor (2009) dan Pambuko (2016).

Hasil penelitian pada variabel inflasi diperoleh nilai $p$-value sebesar 0,4531 $(0,4531>0,05)$, sehingga hipotesis kelima $\left(\mathrm{H}_{5}\right)$ ditolak. Nilai koefisien pada variabel FDR juga memiliki tanda negatif, dan dapat dijelaskan bahwa variabel inflasi tidak memiliki pengaruh yang nyata terhadap tingkat efisiensi Unit Usaha Syariah pada Bank Pembangunan Daerah (BPD) di Indonesai periode 2012-2016. Hasil ini sesuai dengan penelitian yang dilakukan oleh Sufian dan Habibullah (2010), dan Pambuko (2016).

\section{SIMPULAN}

Berdasarkan hasil pengukuran DEA menunjukkan bahwa efisiensi Bank Pembangunan Daerah (BPD) Syariah dengan asumsi pendekatan intermediasi selama jangka waktu penelitian masih dikategorikan inefisien, hal ini dikarenakan rata-rata nilai efisiensi BPD Syariah berkisar pada angka 80 persen.Variabel Ukuran Bank, Return On Asset (ROA) dan Financing to Deposit Ratio (FDR) berpengaruh signifikan dan memiliki hubungan positif terhadap tingkat efisiensi Bank Pembangunan Daerah (BPD) Syariah selama periode 2012-2016. 
Puspita, et al/ Jurnal Ekonomi Syariah Teori dan Terapan Vol.5 No.10 Oktober 2018: 800-815; DETERMINAN TINGKAT EFISIENSI BANK PEMBANGUNAN DAERAH (BPD) SYARIAH DI INDONESIA: TWOSTAGE DATA ENVELOPMENT ANALYSIS

Variabel Non Performing Financing (NPF) tidak berpengaruh pada level signifikan $5 \%$ dan memiliki hubungan positif terhadap tingkat efisiensi Bank Pembangunan Daerah (BPD) Syariah selama periode 2012-2016.Variabel Inflasi tidak mempengaruhi tingkat efisiensi Bank Pembangunan Daerah (BPD) Syariah selama periode 2012-2016.

\section{DAFTAR PUSTAKA}

Abidin, Zaenal dan Endri. 2009. Kinerja Efisiensi Teknis Bank Pembangunan Daerah: Pendekatan Data Envelopment Analysis (DEA). Jurnal Akuntansi dan Keuangan, Vol. 11, No.1, pp.21-29.

Al-Quran dan Terjemahan.2014. Kementrian Agama Rl dengan Transliterasi Arab-Latin.

Basyaib, Fachmi. 2007. Kevangan Perusahaan. Edisis Pertama. Jakarta: Kencana Prenada Media Group.

Begum, Nur Sabrina.2015. Analisis Tingkat Efisiensi Perbankan Syariah Di Indonesia Tahun 2010-2014 Dengan Menggunakan Metode Data Envelopment Analysis.Skripsi tidak diterbitkan. Universitas Airlangga.

Berger, A.N dan Mester, L, J. 1997. Inside The Black Box: What Explains Differences In The Efficiency of Financial Institusions. Journal of Banking and Finance, 21, 895-947.

Fadhlullah, Ahmad H. 2015. Efisiensi Bank Pembangunan Daerah: Pendekatan Stochastic Frontier. Signifikan, Vol. 4, No.1, April 2015.

Fathony, Moch. 2012. Estimasi Dan FaktorFaktor Yang Mempengaruhi Efisiensi Bank Domestik Dan Asing Di Indonesia. Jurnal Kevangan dan Perbankan, Vol.16, No.2, Mei 2012, hlm.223-237.

Firdaus, Muhammad F. dan Muhamad Nadratuzzaman H. 2013.Efisiensi Bank
Umum Syariah Menggunakan Pendekatan Two-Stage Data Envelopment Analysis.Buletin Ekonomi dan Perbankan, Vol. 16, No. 2, Oktober 2013.

Gujarati, Damodar. 2003. Basic Econometrics. Fourth Edition. Boston: McGraw-Hill.

Hadad, M. Santoso, W. Dhaniel, I. Mardhanugraha, E. 2003. Analisis Efisiensi Industri Perbankan Indonesia: Penggunaan Metode Non-Parametrik Data Envelopment Analysis (DEA). Research Paper Bank Indonesia, No.7/5.

Ismail, Farhana, Rossazana Ab. Rahim, dan M. Shabri Abd. Majid. 2012. Determinant of Efficiency in Malaysia Banking Sector. International Procedings of Economics Development and Research, Vol. 43, pp.238.

Kamaruddin, dkk.2008. Asseing Production Efficiency of Islamic Banks and Conventional Bank Islamic Windows in Malaysia.International Journal of Business and Management Science, Vol 1 (1), hlm.31-48.

Mankiw, N. Gregory. 2004. Pengantar Ekonomi Makro. Edisi Ketiga. Jakarta: Salemba Empat.

Mishkin, Frederic S. 2010. Ekonomi Uang, Perbankan dan Pasar-Pasar Keuangan. Jakarta: Salemba Empat.

Muharam, Harjum dan Rizki Pusvitasari. 2007. Analisa Perbandingan Efisiensi Bank Syariah di Indonesia dengan Metode Data Envelopment Analysis Periode Tahun 2005. Jurnal Fakultas Ekonomi Universitas Diponegoro, Vol.11, No. 03, Desember 2007.

Noor, M.A.N.M dan Hayati, N.A. 2011 . The Determinants of Islamic Bank's Efficiency and the Impact of the 1998 and 2008 Financial Crises. Review of Islamic Economics, Vol. 15, No. 1, pp.37-69. 
Puspita, et al/ Jurnal Ekonomi Syariah Teori dan Terapan Vol.5 No.10 Oktober 2018: 800-815; DETERMINAN TINGKAT EFISIENSI BANK PEMBANGUNAN DAERAH (BPD) SYARIAH DI INDONESIA: TWOSTAGE DATA ENVELOPMENT ANALYSIS

Pambuko, Zulfikar Bagus. 2016. Determinan Tingkat Efisiensi Perbankan Syariah Di Indonesia: Two Stages Data Envelopment Analysis. CAKRAWALA, Vol. XI, No. 2, Desember 2016.

Permono, Iswardono S. dan Darmawan.2000. Analisis Efisiensi Industri Perbankan Di Indonesia (Studi Kasus Bank-Bank Devisa Di Indonesia Tahun 1991-1996).Jurnal Ekonomi Dan Bisnis Indonesia, XV(1).

Pratikno, Heri dan lis Sugianto. 2011. Kinerja Efisiensi Bank Syariah Sebelum dan Sesudah Krisis Global Berdasarkan Data Envelopment Analysis. Jurnal Ekonomi Bisnis, Vol.16(2), pp.108-117.

Rabbani, Farhan. 2014. Analisis Perbandingan Efisiensi Bank Pembangunan Daerah dan Unit Usaha Syariah BPD Sebelum dan Sesudah Penerapan BPD Regional Champion (BRC) dengan Metode Data Envelopment Analysis (DEA). Skripsi tidak diterbitkan. Universitas Syarif Hidayatullah.

Ramly, Ar Royyan. 2015. Tingkat Efisiensi Bank Pembangunan Daerah (BPD) Di Indonesia Periode 2012-2014. Disertasi tidak diterbitkan. Universitas Serambi Mekkah.

Siamat, Dahlan. 2001. Manajemen Lembaga Keuangan. Edisi Ketiga. Jakarta: Badan Penerbit Fakultas Ekonomi Universitas Indonesia.

Sufian, Fadzlan dan Noor M.A.N.M. 2009. The Determinants of Islamic Bank's Efficiency Changes Empirical Evidence from the MENA and Asian Banking Sectors. International Journal of Islamic and Middle Eastren Finance and Management, Vol. 23, No. 3.

Sufian, Fadzlan dan Muzafar Shah Habibullah. 2010. Development in the Efficiency of the Thailand Banking Sector: a DEA Approach. International Journal of Development Issues, Vol. 9, No. 3, pp 226-245.

Sugiyono. 2003. Metode Penelitian Bisnis. Bandung: Pusat Bahasa Departemen Pendidikan Nasional.

Undang-Undang Republik Indonesia. 1962. Undang-Undang Republik Indonesia Nomor 13 Tahun 1962 Tentang Ketentuan-Ketentuan Pokok Bank Pembangunan Daerah.

Weston, J. Fred dan Thomas E. Copeland. 1998. Manajemen Keuangan. Edisi 8. Jakarta: Bina Rupa Aksara.

Wheelock, D.C dan P. Wilson. 1999. Technical Progress Inefficiency and Productivity Change in US Banking. Journal of Money, Credit and Banking, Vol. 31, pp 212-234.

Yudistira, D. 2004. Efficiency in Islamic Banking: An Empirical Analysis of Eighteen Banks. Islamic Economic Studies, 12(1). 